\title{
Pathogenic Variation and Molecular Characterization of Macrophomina phaseolina, the Cause of Sesame Charcoal Rot
}

\author{
Yousef, $\mathbf{H}$.
}

Received: 27 May 2021 / Accepted: 10 June 2021 / Published online: 11 June 2021.

CEgyptian Phytopathological Society 2021

\begin{abstract}
Macrophomina phaseolina (Tassi) Goid is one of the most important soil-borne fungi that affects sesame and causes charcoal rot disease, with a great economic challenge to sesame growers worldwide. Pathogenic and molecular characterizations of eleven $M$. phaseolina isolates collected from different geographical regions in Egypt were carried out to determine the pathogenicity and genetic diversity. Pathogenicity tests showed a pathogenic variability among the isolates. The identification of $M$. phaseolina isolates was confirmed by a specific primer and analyzed for genetic diversity using random amplified polymorphic DNA (RAPD) and inter-simple sequence repeat (ISSR) markers. The correlation between RAPD analysis of $M$. phaseolina isolates and their pathogenicity were estimated. Cluster analysis placed the isolates in two distinct clusters and exhibited clear correlation with their pathogenicity. Analysis of ISSR profiles revealed distinct genetic diversity among isolates and showed different clusters according to the geographical regions, in which close geographic origins tend to group nearly. The present study clearly demonstrated that $M$. phaseolina isolates which were obtained from different geographical regions were highly variable. RAPD and ISSR markers were suitable to reflect the genetic diversity among the studied isolates and could help in DNA finger printing which can be used in future breeding programs of sesame.
\end{abstract}

Keywords: Sesame, Sesamum indicum, Macrophomina phaseolina, genetic diversity, DNA, RAPD, ISSR, cluster analysis, molecular markers.

*Correspondence: Yousef, $\mathrm{H}$.

E-mail: heba.yousef@live.com

Heba Yousef

(D) https://orcid.org/0000-0003-3314-8856

Plant Pathology Research Institute, Agricultural

Research Center, 12619, Giza, Egypt.

\section{INTRODUCTION}

Sesame (Sesamum indicum L.) is grown as an oilseed crop in tropical and subtropical parts of the world (Premalatha et al., 2020). Sesame plants get attacked with several diseases during their growing stages causing significant quantitative and qualitative losses in seed and oil yield (Deepthi et al., 2014).

Macrophomina phaseolina (Tassi) Goid. causes charcoal rot disease on more than 500 plant species worldwide (Ghosh et al., 2018 and Hussien et al., 2018). The disease has caused economically critical losses on oilseed plants, particularly on corn, cotton, sesame, and sunflower (Machado et al., 2019). Charcoal rot is a destructive soil borne disease that favors high temperatures and dry weather or when plants are stressed by unfavorable environmental conditions (Etebarian, 2006 and Negreiros et al., 2019). Hence, a diagnostic tool for identifying the different isolates of this pathogen is critically needed. Variations in microsclerotia size, cultural characteristics, and pathogenicity were used to identify and classify $M$. phaseolina isolates (Aboshosha et al., 2007 and Saleh et al., 2010).

Molecular markers have been proven to be useful in characterizing and assessing genetic diversity within and across species and populations (Almeida et al., 2003; Al-Dhabaan et al., 2018; Mezzomo et al., 2018). Random Amplified Polymorphic DNA (RAPD) analysis is one of the most common and convenient molecular marker techniques. It is usually utilized in genetic mapping, taxonomy, and polygenic research (Jana et al., 2003; Fuhlbohm et al., 2013). In RAPD analysis, genomic DNA is amplified by PCR using short primers with an arbitrary sequence causing multiple amplicons of various lengths which are analyzed by gel electrophoresis, resulting in characteristic fingerprints of genomic DNA. As a result, it detects nucleotide sequence polymorphisms that occur at random throughout the genome (Sucher and Carles, 2008). RAPDs have many benefits, including speed, low cost, and the ability to identify variation in the genome with little genomic DNA as a template (Gajera et al., 2010).

Inter simple sequence repeat (ISSR) technique is a PCR-based technique that involves amplification of DNA segment located at an amplifiable distance in between two identical microsatellites repeat regions aligned in opposite 
directions. The technique utilizes microsatellites, usually 16-25 bp long. ISSR uses a synthetic nucleotide primer to determine genetic variability and DNA fingerprints. This technique has been used successfully in a variety of taxonomic and genetic diversity studies (Hamza et al., 2013). ISSRs are extremely reliable because of high annealing temperature and longer sequence (Yao et al., 2008).

Both RAPD and ISSR markers have been successfully used to differentiate several fungi (Bridge, 1998). Furthermore, these techniques are useful for grouping rather than identification. Therefore, a rapid diagnostic test that can exactly identify and detect $M$. phaseolina isolates is required. In fungi, the internal transcribed spacer (ITS) region is an excellent target for phylogenetic study (Ghosh et al., 2018). Nevertheless, ITS amplification has indicated that isolates belonged to one single species (Almomani et al., 2013).

In plant disease control, accurate diagnosis and early detection of pathogens are critical steps. Species-specific oligonucleotide primers can be used to quickly detect and identify M. phaseolina by polymerase chain reaction (PCR) (Babu et al., 2007 and Santos et al., 2020).

Both morphological examination and molecular techniques were used to characterize isolates of M. phaseolina isolated from sesames in different geographical distributions (Babu et al., 2007 and Sharma et al., 2013). Even though only one species of the genus Macrophomina was identified, its different isolates vary in their morphology, such as colony morphology, microscopic examination of microsclerotia, pycnidia, and pathogenicity (Saleh et al., 2010). Molecular markers succeeded in assessing the genetic diversity and phylogenetic relationships between various isolates to differentiate and account for their variation in pathogenicity (Purkayastha et al., 2004).

The objectives of this study were to detect and confirm the identification of M. phaseolina using specific primers and evaluate the relationship between the genetic diversity of M. phaseolina isolates and both the geographic origin and pathogenicity testing by using RAPD and ISSR markers techniques.

\section{MATERIALS AND METHODS}

\section{Fungal Isolates:}

Infected sesame plants, showing charcoal-rot symptoms, were collected from different governorates of Egypt (Table 1). To isolate $M$. phaseolina, five small $(0.5 \mathrm{~cm})$ epidermal sections were excised from diseased tissues then sterilized in $75 \%$ ethanol for $30 \mathrm{sec}$, transferred to $2.5 \%$ sodium hypochlorite for $30 \mathrm{sec}$ and washed in sterile water for $1 \mathrm{~min}$. Surface disinfested tissue samples were placed on potato dextrose agar (PDA) containing chloramphenicol $(0.1 \mathrm{mg} / \mathrm{ml})$. Plates were incubated at $28^{\circ} \mathrm{C}$ in the dark for 5 days. The isolated fungi were purified using the hyphal tip techniques then they were identified according to Dhingra and Sinclair (1973).

\section{Table (1): List of $M$. phaseolina isolates from different geographical regions in Egypt.}

\begin{tabular}{|c|c|c|}
\hline Isolate's code & Geographical origin & Host \\
\hline MP-1 & Qalyubia & Sesame \\
\hline MP-2 & Beheira & Sesame \\
\hline MP-3 & Sharqia & Sesame \\
\hline MP-4 & Dakahlia & Sesame \\
\hline MP-5 & Giza & Sesame \\
\hline MP-6 & Kafr El Sheikh & Sesame \\
\hline MP-7 & Faiyum & Sesame \\
\hline MP-8 & Beni Suef & Sesame \\
\hline MP-9 & Minya & Sesame \\
\hline MP-10 & Asyut & Sesame \\
\hline MP-11 & Sohag & Sesame \\
\hline
\end{tabular}

Morphological and cultural characteristics of M. phaseolina isolates:

Eleven M. phaseolina isolates were grown on PDA medium to study their morphological and cultural characteristics. Agar discs $(5 \mathrm{~mm})$ were plugged from 7 days old pure culture and transferred to the center of sterilized Petri dishes containing PDA medium. The plates were incubated at $27^{\circ} \mathrm{C}$ for 7 days. The experiment was repeated three times, each one consisting of 3 plates. On PDA cultures, morphological properties of pure cultures such as mycelial growth diameter, colony color, and sclerotial development and size were investigated (Abd ElGhany, 1998). Sclerotia size were measured using a digital camera light microscope after culture slides were prepared with a $25 \%$ glycerol solution. For each isolate, the sizes of 10 randomly selected sclerotia were measured, and their means were calculated.

Pathogenicity tests of $M$. phaseolina isolates under greenhouse conditions:

Inoculum of Macrophomina phaseolina was prepared using sorghum - coarse sand - water $(2: 1: 2 \mathrm{v} / \mathrm{v})$ medium according to Ibrahim (2006). 
Inocula of $M$. phaseolina were mixed thoroughly with sterilized soil of each sterilized pot $(30 \mathrm{~cm}$ diameter $\times 27 \mathrm{~cm}$ height) at the rate of $3 \% \mathrm{w} / \mathrm{w}$ and covered with a thin layer of sterilized soil. Infested pots were irrigated and kept for 7 days until sowing; non inoculated pots were used as a control. Ten sterilized sesame seeds Giza $32 \mathrm{cv}$. were sown per pot; five replicates (pots) were used for each treatment. Disease assessment was made 15 and 45 days after planting for pre- and post-emergence damping-off, respectively. The percentage of charcoal rot was estimated, after 90 days from planting and calculations were processed according to Manici et al. (1992) as follows:

$\%$ Pre-emergence =

Number of non - germinated seeds Number of sown seeds

$\%$ Post-emergence $=$ $\frac{\text { Number of dead seedlings }}{\text { Number of germinated seeds }} \times 100$

\% Charcoal rot incidence $=$ $\frac{\text { Number of diseased plants }}{\text { Total number of plants }} \times 100$

\section{Genomic DNA extraction:}

A $5 \mathrm{~mm}$ culture plug from a 2-day-old culture of each isolate was grown in the dark at $28^{\circ} \mathrm{C}$ for 5 days in $250 \mathrm{ml}$ glass bottles containing $50 \mathrm{ml}$ potato dextrose broth (PDB). Mycelia were filtered through Whatman No. 1 filter paper, then frozen in liquid nitrogen, and ground with mortar and pestle. Genomic DNA was extracted using DNeasy Plant Mini Kit (Qiagen, Santa Clarita, CA) according to the manufacturer's instructions. Quantification of the DNA concentration in different samples was done by measuring the optical density at $260 \mathrm{~nm}$ and stored at $-20^{\circ} \mathrm{C}$ for further use.

\section{PCR amplification and gel electrophoresis:}

DNA samples of each isolate were subjected to molecular analysis by amplifying the genomic DNA in a total volume of $25 \mu \mathrm{l}$ using 18 RAPD random primers and 15 ISSR primers (Table 2). PCR amplifications were performed using $7 \mu$ of GoTaq ${ }^{\circledR}$ Green Master Mix (2X) (Promega Corporation, Madison, USA), $14 \mu$ of nucleasefree water, $2 \mu \mathrm{l}$ of primer and $2 \mu \mathrm{l}$ of DNA template $(25-35 \mathrm{ng} / \mu \mathrm{l})$. The DNA amplification was carried out using a thermal cycler. Amplification was carried out using initial denaturation at $95^{\circ} \mathrm{C}$ for $4 \mathrm{~min}$ followed by 45 cycles at $94^{\circ} \mathrm{C}$ for $1 \mathrm{~min}, 35^{\circ} \mathrm{C}$ for $1 \mathrm{~min}, 72^{\circ} \mathrm{C}$ for $2 \mathrm{~min}$ and final extension step at $72{ }^{\circ} \mathrm{C}$ for 5 $\min$.

The amplification product was separated in a $1.5 \%$ agarose gel using $1 \mathrm{X}$ TBE buffer $(89 \mathrm{mM}$ Tris-HCl, $89 \mathrm{mM}$ boric acid and $2 \mathrm{mM}$ EDTA $\mathrm{pH}$ 8.0). The gel was stained with ethidium bromide $(0.50 \mu \mathrm{g} / \mathrm{ml})$ and visualized under UV to confirm DNA amplification. The amplified fragments were photographed using a UV trans-illuminator and analyzed with a gel documentation system. DNA ladder (100 bp) (GeneDireX, USA) was used as standard DNA.

Table (2): List of used primers and their base sequences according to Purkayastha $e t$ al., 2006 and Moulin et al., 2012.

\begin{tabular}{|c|c|}
\hline primers & Sequences \\
\hline RAPD-1 & $\left(5^{\prime}\right.$ - GGTGCGGGAA-3') \\
\hline RAPD-2 & (5'- GTTTCGCTCC-3') \\
\hline RAPD-3 & (5'- GTAGACCCGT-3') \\
\hline RAPD-4 & (5'- AAGAGCCCGT-3') \\
\hline RAPD-5 & $\left(5^{\prime}-\mathrm{AACGCGCAAC-3^{ \prime } )}\right.$ \\
\hline RAPD-6 & (5'- CCCGTCAGCA-3') \\
\hline RAPD-7 & (5'- CAGGCCCTTC-3') \\
\hline RAPD-8 & (5'-AGGTGACCGT-3') \\
\hline RAPD-9 & (5'-AGTCAGCCAC-3') \\
\hline RAPD-10 & (5'-GTGATCGCAG-3') \\
\hline RAPD-11 & $\left(5^{\prime}-\mathrm{CAATCGCCGT-3^{ \prime } )}\right.$ \\
\hline RAPD -12 & (5'-TCGGCGATAG-3') \\
\hline RAPD-13 & (5'-TCTGTGCTGG-3') \\
\hline RAPD-14 & $\left(5^{\prime}-\mathrm{TTCCGAACCC}-3^{\prime}\right)$ \\
\hline RAPD-15 & $\left(5^{\prime}\right.$-CCGCATCTAC-3') \\
\hline RAPD-16 & (5'-GAACGGACTC-3') \\
\hline RAPD-17 & (5'-AGGGGTCTTG-3') \\
\hline RAPD-18 & (5'-GAAACGGGTG-3') \\
\hline ISSR-1 & $\mathrm{TC}(\mathrm{GACA})_{4}$ \\
\hline ISSR-2 & $(\mathrm{AG})_{8} \mathrm{~T}$ \\
\hline ISSR-3 & $(\mathrm{CT})_{8} \mathrm{~T}$ \\
\hline ISSR-4 & $(\mathrm{CA})_{8} \mathrm{G}$ \\
\hline ISSR-5 & $(\mathrm{TG})_{8} \mathrm{~A}$ \\
\hline ISSR-6 & $(\mathrm{CAG})_{5} \mathrm{AT}$ \\
\hline ISSR-7 & $(\mathrm{CAC})_{3} \mathrm{GC}$ \\
\hline ISSR-8 & (GT)6CC \\
\hline ISSR -9 & $(\mathrm{AG})_{8} \mathrm{C}$ \\
\hline ISSR-10 & $(\mathrm{AC})_{8} \mathrm{CT}$ \\
\hline ISSR-11 & $(\mathrm{CT})_{8} \mathrm{G}$ \\
\hline ISSR-12 & $(\mathrm{GGAT})_{3} \mathrm{AG}$ \\
\hline ISSR -13 & $(\mathrm{ATG})_{6}$ \\
\hline ISSR-14 & $(\mathrm{AC})_{8} \mathrm{~T}$ \\
\hline ISSR-15 & $(\mathrm{GAA})_{6} \mathrm{AA}$ \\
\hline
\end{tabular}




\section{Molecular characterization:}

Genomic DNA of the tested isolates of $M$. phaseolina were extracted and used for molecular identification. Then, PCRs were performed using the universal fungal primers ITS4/ITS5 to amplify the ITS1-5.8S-ITS2 region and specific primers for M. phaseolina MpKF1/MpKR1 (5'CCGCCAGAGGACTATCAAAC-3'/5'CGTCCGAAGCGAGGTGTATT-3') located in ITS1 and ITS2 regions, respectively. PCRs were conducted as follows: $5 \mathrm{~min}$ at $95^{\circ} \mathrm{C}$; followed by 35 cycles of $45 \mathrm{sec}$ at $94^{\circ} \mathrm{C}, 45 \mathrm{sec}$ at 55 or $60^{\circ} \mathrm{C}$ (depending on the primer pair), and $1 \mathrm{~min}$ at $72^{\circ} \mathrm{C}$; and a final extension of $10 \mathrm{~min}$ at $72^{\circ} \mathrm{C}$ (White et al., 1990). A negative control with all reaction reagents except the DNA template was included with each set of PCR amplification reactions.

\section{Data analysis:}

The data obtained from molecular analyses of M. phaseolina isolates were analyzed with a gel documentation system. Relative relatedness among isolates was determined using CLIQS v1.1 software. A dendrogram was constructed from the similarity coefficient data by the unweighted pair-group method with arithmetic mean (UPGMA) clustering algorithm.

\section{Statistical analysis:}

Comparison means were performed using Duncan's at $p<0.05$ and the standard error was calculated using the Statistical analysis software "COStat 6.4" (CoStat, 2005).

\section{RESULTS}

\section{Morphological and cultural characteristics of M. phaseolina isolates:}

By using morphological characterization, all the used isolates of $\mathrm{M}$. phaseolina showed different phenotypes when grown on PDA medium. Appressed mycelium was observed on the culture plate with microsclerotia imbedded within the hyphae. The color of colonies was white to gray and black (Fig. 1). Mycelial growth diameter of isolates ranged from 65.79 to 95.12 $\mathrm{mm}$.

Some of the isolates had larger sclerotia with higher rates of mycelial growth. The color of the sclerotia was light brown in the beginning which became darker with age and finally brown to black, microsclerotia varied in shape: either irregular, spherical, or oval. Variations were also observed among these isolates regarding the size of their sclerotia. The individual average sclerotia sizes of isolates ranged from 12.68 to $36.80 \mu \mathrm{m}$ (Table 3). The isolate having the biggest sclerotia size was MP-3 with $36.80 \mu \mathrm{m}$, followed by MP11 with $33.56 \mu \mathrm{m}$, MP-9 with $31.45 \mu \mathrm{m}$, and MP10 with $30.87 \mu \mathrm{m}$. On the other hand, MP-4 had the smallest sclerotia size with $12.68 \mu \mathrm{m}$, followed by MP-5 with $13.01 \mu \mathrm{m}$.

Table (3): Morphological variations among isolates of M. phaseolina.

\begin{tabular}{lcccc}
\hline \multicolumn{1}{c}{ Isolate code } & $\begin{array}{c}\text { Mycelial growth } \\
\text { diameter }(\mathrm{mm})\end{array}$ & $\begin{array}{c}\text { Sclerotia size } \\
(\mu \mathrm{m})\end{array}$ & Phenotype & $\begin{array}{c}\text { Mycelial growth } \\
\text { color }\end{array}$ \\
\hline MP-1 & $85.17^{\mathrm{ef}^{*}}$ & $13.74^{\mathrm{ef}}$ & Appressed & Gray \\
MP-2 & $87.23^{\mathrm{cd}}$ & $15.23^{\mathrm{def}}$ & Feathery & Gray \\
MP-3 & $95.12 \mathrm{a}$ & $36.80^{\mathrm{a}}$ & Appressed & black \\
MP-4 & $57.98^{\mathrm{j}}$ & $12.68^{\mathrm{f}}$ & Feathery & white \\
MP-5 & $65.79^{\mathrm{i}}$ & $13.01^{\mathrm{f}}$ & Appressed & white \\
MP-6 & $84.23^{\mathrm{f}}$ & $18.28^{\mathrm{d}}$ & Feathery & Gray \\
MP-7 & $86.45^{\mathrm{de}}$ & $16.94^{\mathrm{de}}$ & Appressed & Gray \\
MP-8 & $79.86^{\mathrm{h}}$ & $24.12^{\mathrm{c}}$ & Feathery & Gray \\
MP-9 & $88.43^{\mathrm{c}}$ & $31.45^{\mathrm{b}}$ & Appressed & black \\
MP-10 & $82.51^{\mathrm{g}}$ & $30.87^{\mathrm{b}}$ & Feathery & Gray \\
MP-11 & $92.08^{\mathrm{b}}$ & $33.56^{\mathrm{b}}$ & Appressed & black \\
\hline
\end{tabular}

*Means in each column followed by the same letter(s) are not significantly different at $\mathrm{P} \leq 0.05$ according to Duncan`s multiple range test; **Each value represents the mean of three replicates. 


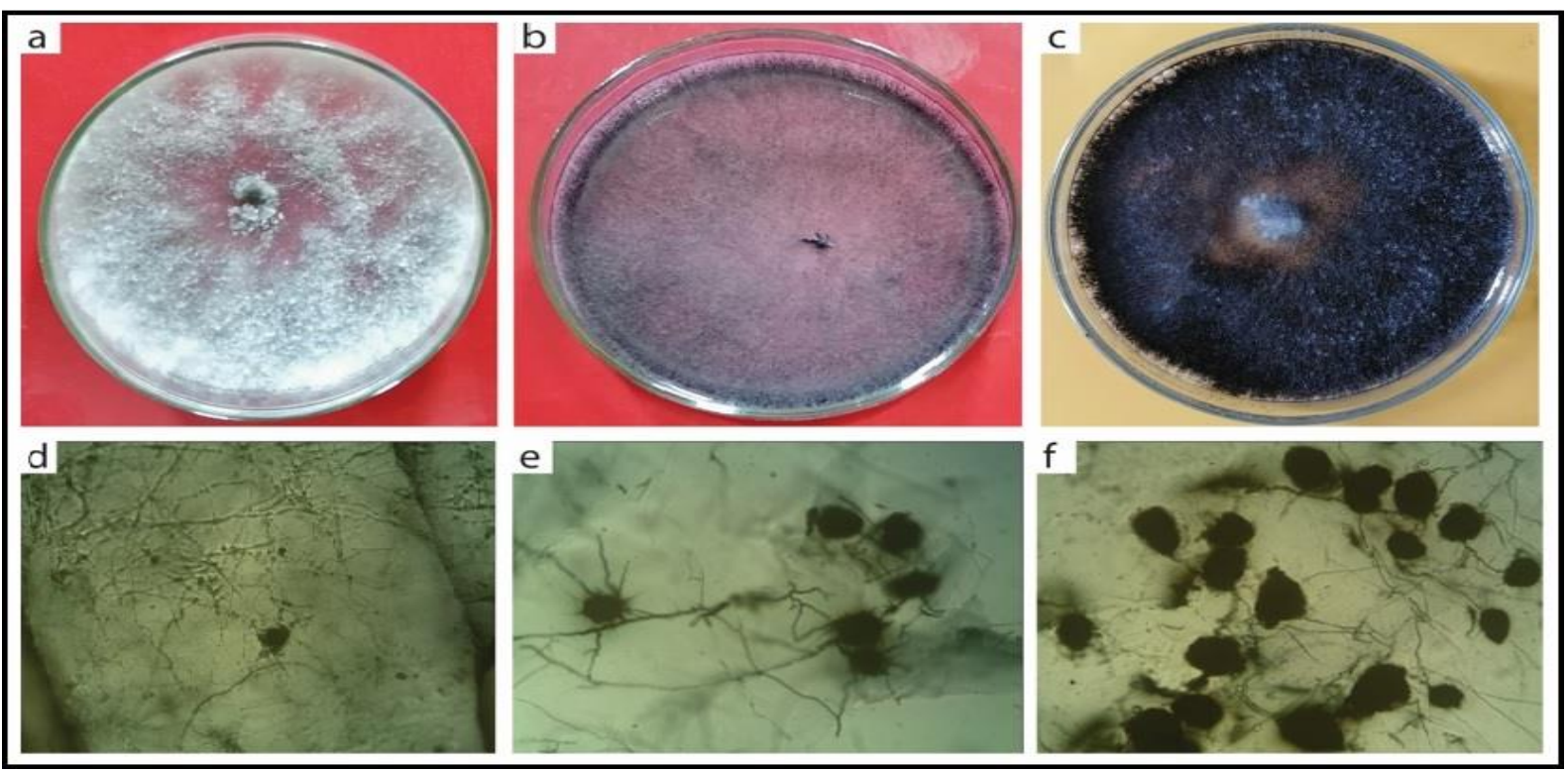

Figure (1): Cultural and morphological characteristics of M. phaseolina. (a, b, and c): Colony on the agar plate. (d, e, and f): Different sizes of microsclerotia.

Pathogenic variability of tested M. phaseolina isolates under greenhouse conditions:

Pathogenicity of different isolates of $M$. phaseolina showed that all isolates were pathogenic on sesame plants (Giza $32 \mathrm{cv}$.) and showed significant differences for incidence of pre- emergence, post- emergence damping off and charcoal rot under greenhouse conditions. Data represented in Table (4) indicate that all the tested isolates were divided into three groups

Table (4): Effect of soil infestation with different isolates of $M$. phaseolina on damping-off and charcoal rot diseases incidence on Giza 32 sesame cv. under greenhouse conditions.

\begin{tabular}{|c|c|c|c|c|c|c|}
\hline \multirow[b]{2}{*}{$\begin{array}{l}\text { Isolate } \\
\text { code }\end{array}$} & \multicolumn{3}{|c|}{ Damping-off $\%$} & \multicolumn{2}{|c|}{ Standing plants $\%$} & \multirow[b]{2}{*}{$\begin{array}{c}\text { Degree of } \\
\text { pathogenicity }\end{array}$} \\
\hline & $\begin{array}{c}\text { Pre- } \\
\text { emergence }\end{array}$ & $\begin{array}{c}\text { Post- } \\
\text { emergence }\end{array}$ & $\begin{array}{c}\text { Total } \\
\text { damping- } \\
\text { off }\end{array}$ & $\begin{array}{c}\text { Charcoal } \\
\text { rot }\end{array}$ & Healthy & \\
\hline MP-1 & $3.33^{\mathrm{d}^{*}}$ & $13.33^{\mathrm{b}}$ & $16.76^{\mathrm{c}}$ & $10.00^{j}$ & $73.34^{\mathrm{a}}$ & Less pathogenic \\
\hline MP-2 & $13.33^{\mathrm{a}}$ & $6.67^{\mathrm{d}}$ & $20.00^{\mathrm{b}}$ & $23.33^{f}$ & $56.67^{\mathrm{c}}$ & Moderately pathogenic \\
\hline MP-3 & $6.67^{c}$ & $13.33^{\mathrm{b}}$ & $20.00^{\mathrm{b}}$ & $60.00^{\mathrm{b}}$ & $20.00^{\mathrm{g}}$ & Highly pathogenic \\
\hline MP-4 & $3.33^{\mathrm{d}}$ & $16.67^{\mathrm{a}}$ & $20.00^{\mathrm{b}}$ & $16.67^{\mathrm{h}}$ & $63.33^{\mathrm{b}}$ & Less pathogenic \\
\hline MP-5 & $10.00^{\mathrm{b}}$ & $13.33^{\mathrm{b}}$ & $23.33^{\mathrm{a}}$ & $26.67^{\mathrm{e}}$ & $50.00^{\mathrm{d}}$ & Moderately pathogenic \\
\hline MP-6 & $13.33^{\mathrm{a}}$ & $6.67^{\mathrm{d}}$ & $20.00^{\mathrm{b}}$ & $6.67^{\mathrm{k}}$ & $73.33^{\mathrm{a}}$ & Less pathogenic \\
\hline MP-7 & $6.67^{c}$ & $16.67^{\mathrm{a}}$ & $23.34^{\mathrm{a}}$ & $20.00^{\mathrm{g}}$ & $56.66^{\mathrm{c}}$ & Moderately pathogenic \\
\hline MP-8 & $3.33^{\mathrm{d}}$ & $10.00^{c}$ & $13.33^{\mathrm{d}}$ & $13.33^{\mathrm{i}}$ & $73.34^{\mathrm{a}}$ & Less pathogenic \\
\hline MP-9 & $3.33^{\mathrm{d}}$ & $10.00^{c}$ & $13.33^{\mathrm{d}}$ & $63.33^{\mathrm{a}}$ & $23.34^{\mathrm{f}}$ & Highly pathogenic \\
\hline MP-10 & $6.67^{\mathrm{c}}$ & $16.67^{\mathrm{a}}$ & $23.43^{\mathrm{a}}$ & $56.67^{\mathrm{c}}$ & $19.99^{\mathrm{g}}$ & Highly pathogenic \\
\hline MP-11 & $10.00^{\mathrm{b}}$ & $13.33^{\mathrm{b}}$ & $13.33^{\mathrm{d}}$ & $46.67^{d}$ & $30.00^{\mathrm{e}}$ & Highly pathogenic \\
\hline
\end{tabular}

*Means in each column followed by the same letter(s) are not significantly different at $\mathrm{P} \leq 0.05$ according to Duncan`s multiple range test. ${ }^{* * E a c h}$ value represents the mean of three replicates. according to the degree of pathogenicity. First group showed high pathogenicity including isolates MP-9, MP-3, MP-10 and MP-11 which recorded charcoal rot incidence $63.3,60,56.7$ and $46.7 \%$ respectively. The second group showed moderate pathogenicity including MP-2, MP-5 and MP-7, while the third group showed low pathogenicity for isolates MP-1, MP-4, MP6 and MP-8. 
Confirmation of molecular identification of $M$. phaseolina isolates by specific primers:

The isolates were identified at the molecular level using species specific primers $(\mathrm{MpKF} / \mathrm{MpKR})$ as designed by Babu et al.
(2007). A fragment of 350-bp was amplified by the primer pair in tested isolates (Fig. 2). The result showed that the isolates collected belonged to the species $M$. phaseolina. No fragment was detected in other fungi used as negative control.

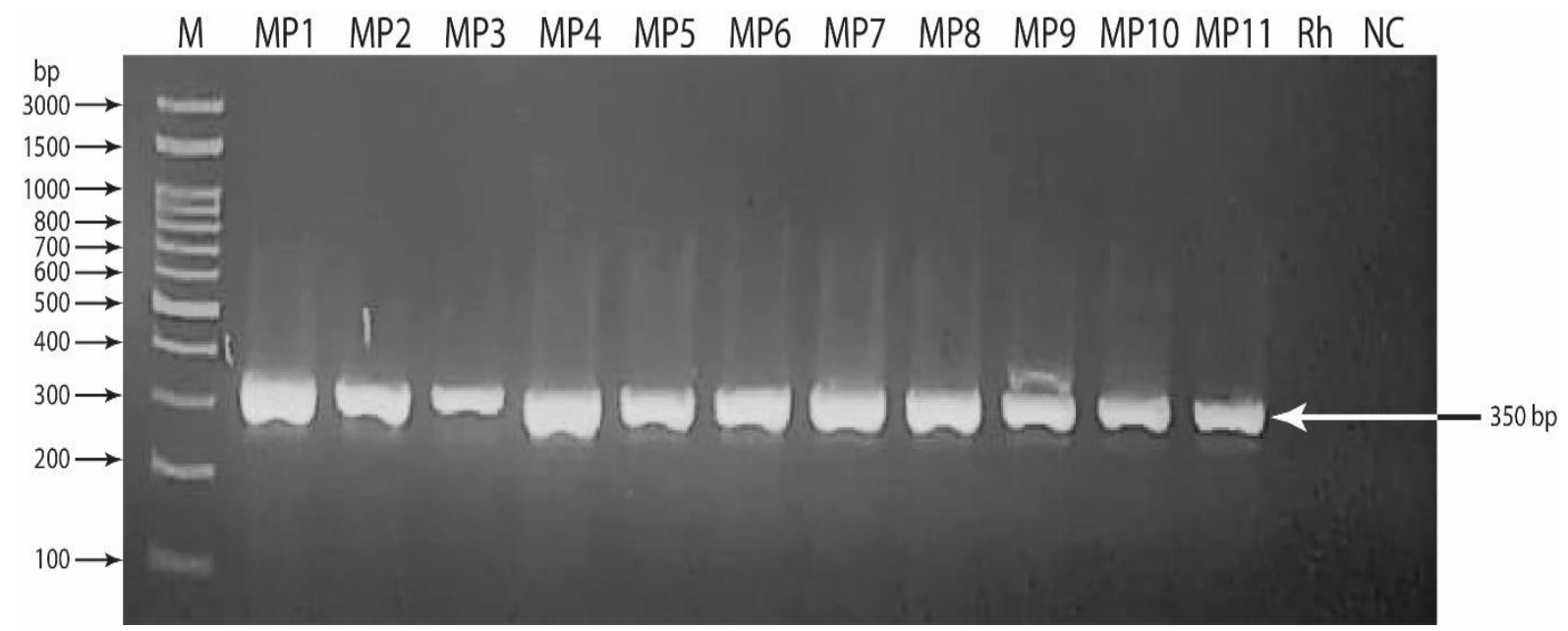

Figure (2): PCR Amplification using specific primer (MpKFI/MpKRI), M: 100bp molecular ladder; 1-11: M. phaseolina isolates; Rh: Rhizoctonia solani is negative control; NC: negative control.

\section{PCR amplification of ITS region:}

Data in Fig. (3) show that the genomic DNA amplification of ITS region of different isolates

of $M$. phaseolina using ITS primers produced one fragment of approximately $650 \mathrm{bp}$.

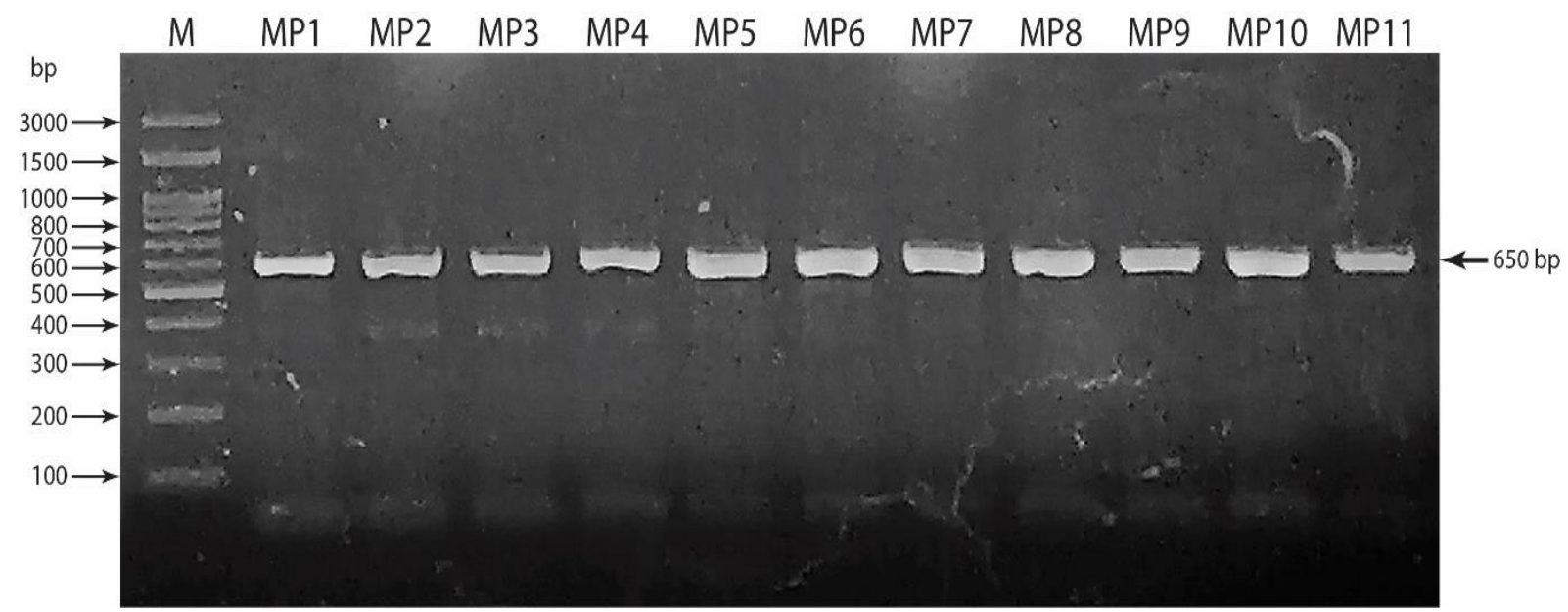

Figure (3): PCR Amplification using Primers ITS-4 and ITS-5 M: 100bp molecular ladder; 1-11: M. phaseolina isolates.

\section{RAPD fingerprinting:}

RAPD analysis that was carried out on the eleven tested $M$. phaseolina isolates showed genetic variation among the isolates. All 18 random primers yielded amplification products in most of the isolates. Out of the 18 primers used for amplification, primer RAPD-3 showed $80 \%$ polymorphism among isolates followed by primers RAPD-5, RAPD-9 and RAPD-12 which showed $70 \%$ polymorphism. These primers generated simple banding patterns that revealed DNA polymorphisms among $M$. phaseolina isolates (Fig. 4). The number of scorable bands for corresponding primers ranged from 1 to 8 with an average of six bands with molecular weight ranging approximately from $200 \mathrm{bp}$ to 1500 bp. RAPD profiles were subjected to UPGMA analysis (Fig. 5). Cluster analysis produced by Primers 3, 5, 9 and 12 revealed that all isolates of M. phaseolina are divided into two clusters, the first cluster included the highly pathogenic isolates, whereas the second cluster contained the moderately pathogenic isolates and the less pathogenic isolates. 

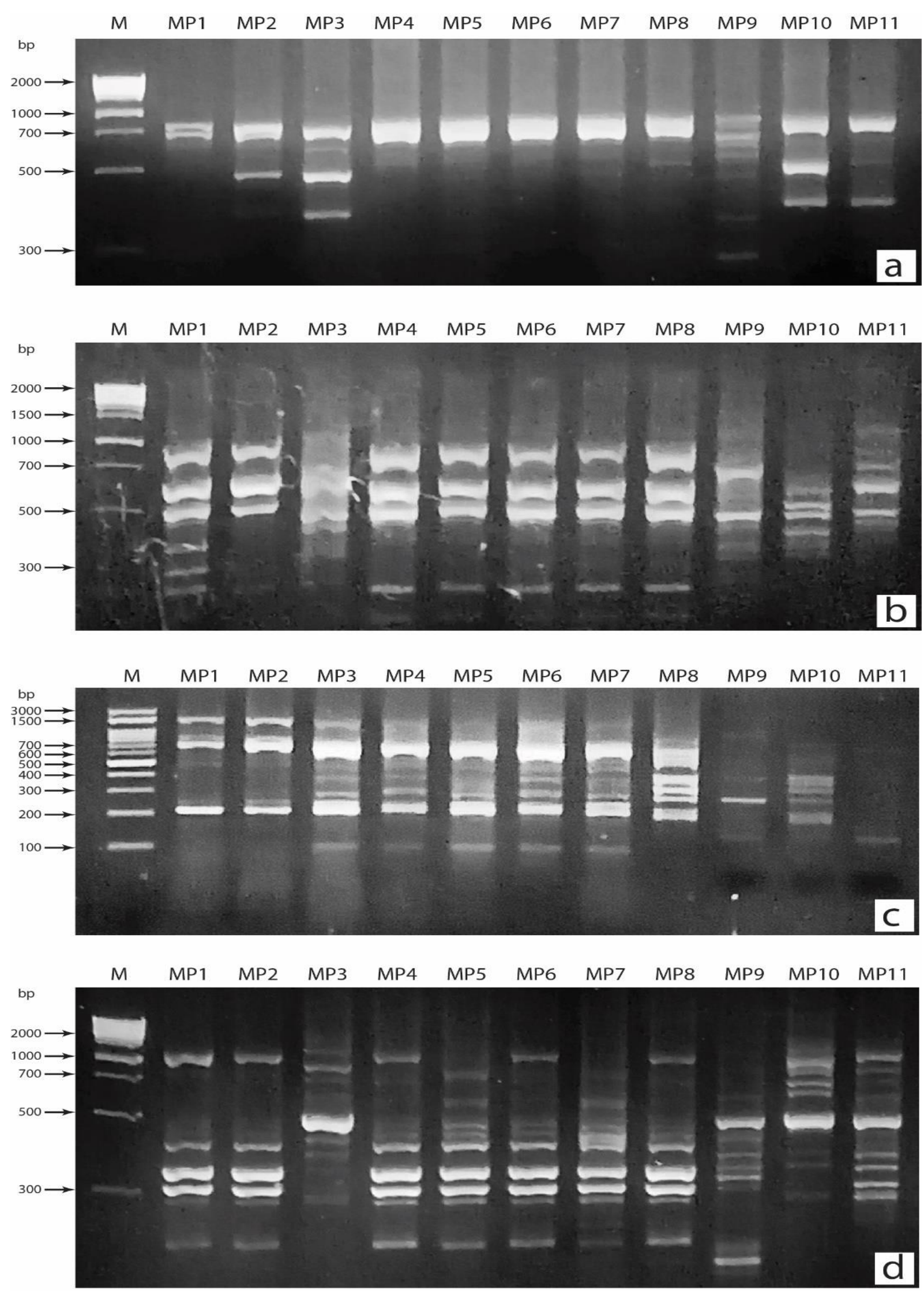

Figure (4): RAPD profiles of eleven different isolates of $M$. phaseolina obtained with random primers (a) RAPD-3, (b) RAPD-5, (c) RAPD-9 and (d) RAPD-12. lanes 1-11 represent the amplicon profile of isolates and $M$ : molecular weight marker. 

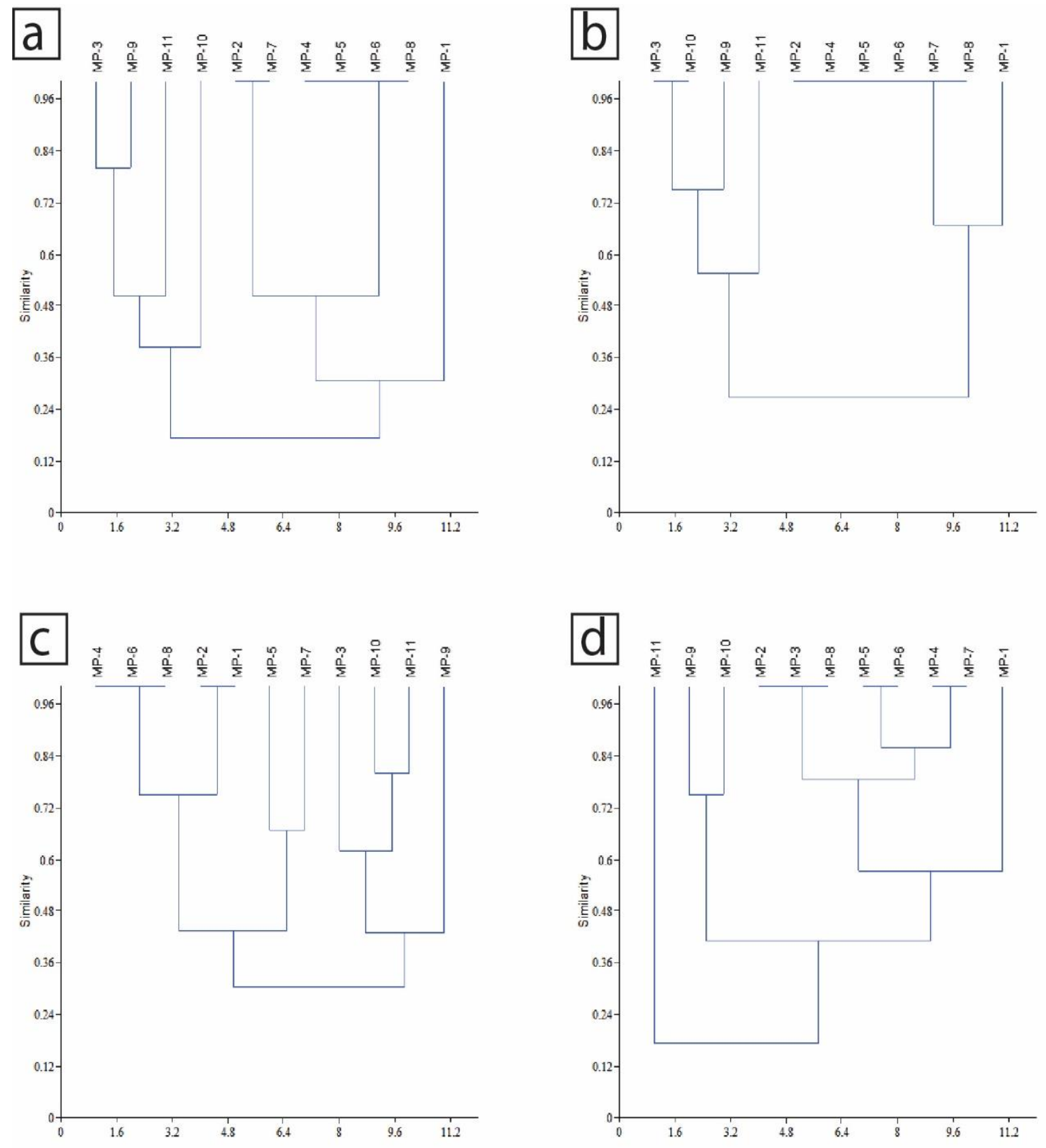

Figure (5): Dendrogram obtained from 11isolates of $M$. phaseolina with Unweighted pair-group method with arithmetic mean (UPGMA) clustering method based on Jaccards coefficient. Distance is based on genetic similarity coefficient.

\section{ISSR Polymorphism:}

All the used 15 ISSR primers successfully generated amplifications with isolates. Four representative primers (ISSR-3, ISSR-6, ISSR-10 and ISSR-14) yielded reproducible and polymorphic amplification patterns on agarose gel. Each reproducible primer amplified 1-8 bands and revealed an average number of 5 bands per ISSR primer. The band size ranged between 200 to $2,000 \mathrm{bp}$, and $85 \%$ of the bands were revealed as polymorphic in these isolates (Fig. 6).
UPGMA clustering of ISSR data produced a dendrogram that could separate the eleven isolates into two groups at an arbitrary level of 96\% similarity (Fig. 7). Dendrogram results showed that the M. phaseolina isolates were clearly differentiated to the specific group according to the geographical origins, however, usually the isolates from nearly geographic origin tend to group closely. 

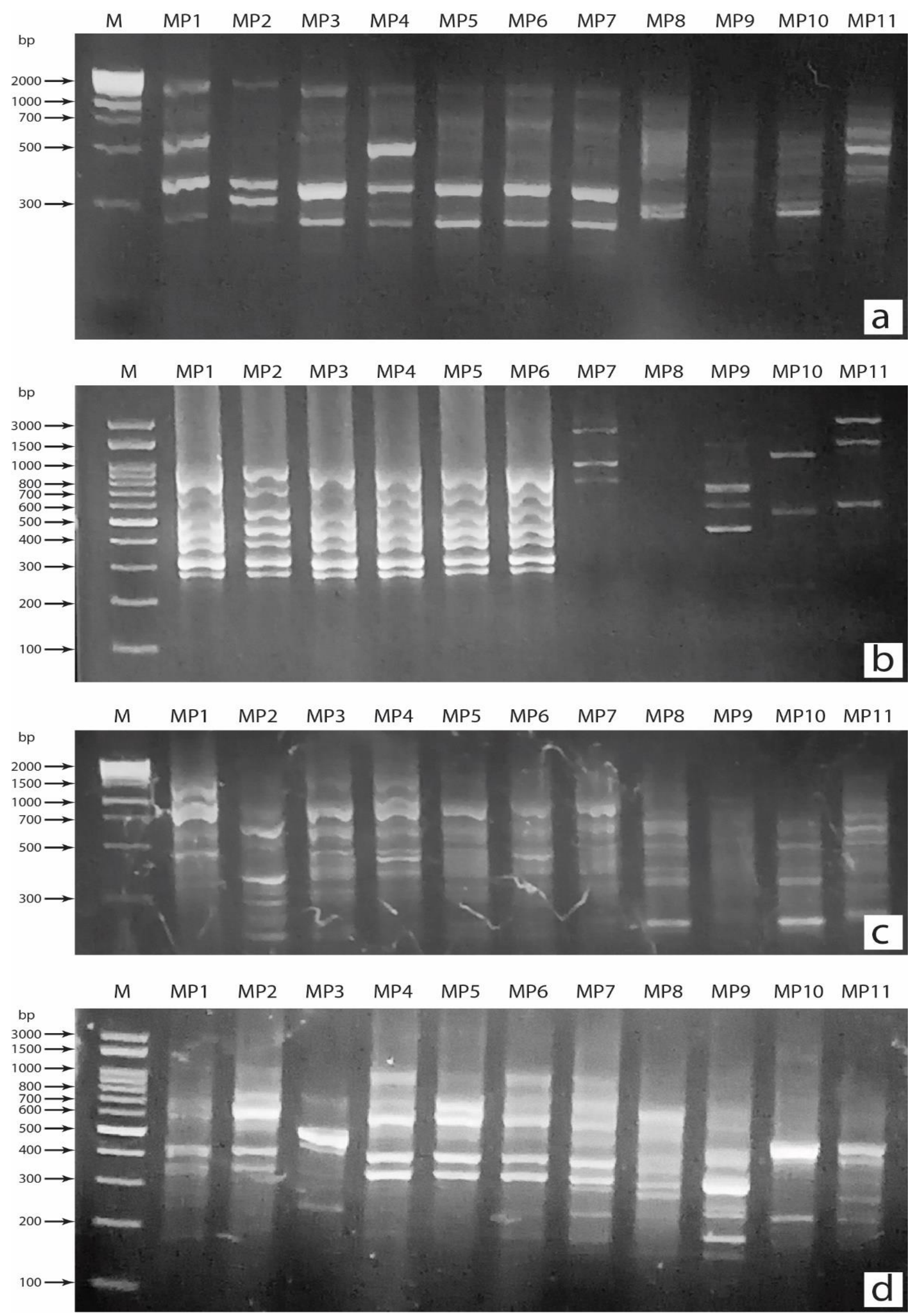

Figure (6): DNA banding patterns of eleven $M$. phaseolina isolates obtained with the ISSR primer (a) ISSR -3, (b) ISSR -6, (c) ISSR -10 and (d) ISSR -14. lanes 1-11 represent the amplicon profile of isolates and M: molecular weight marker. 

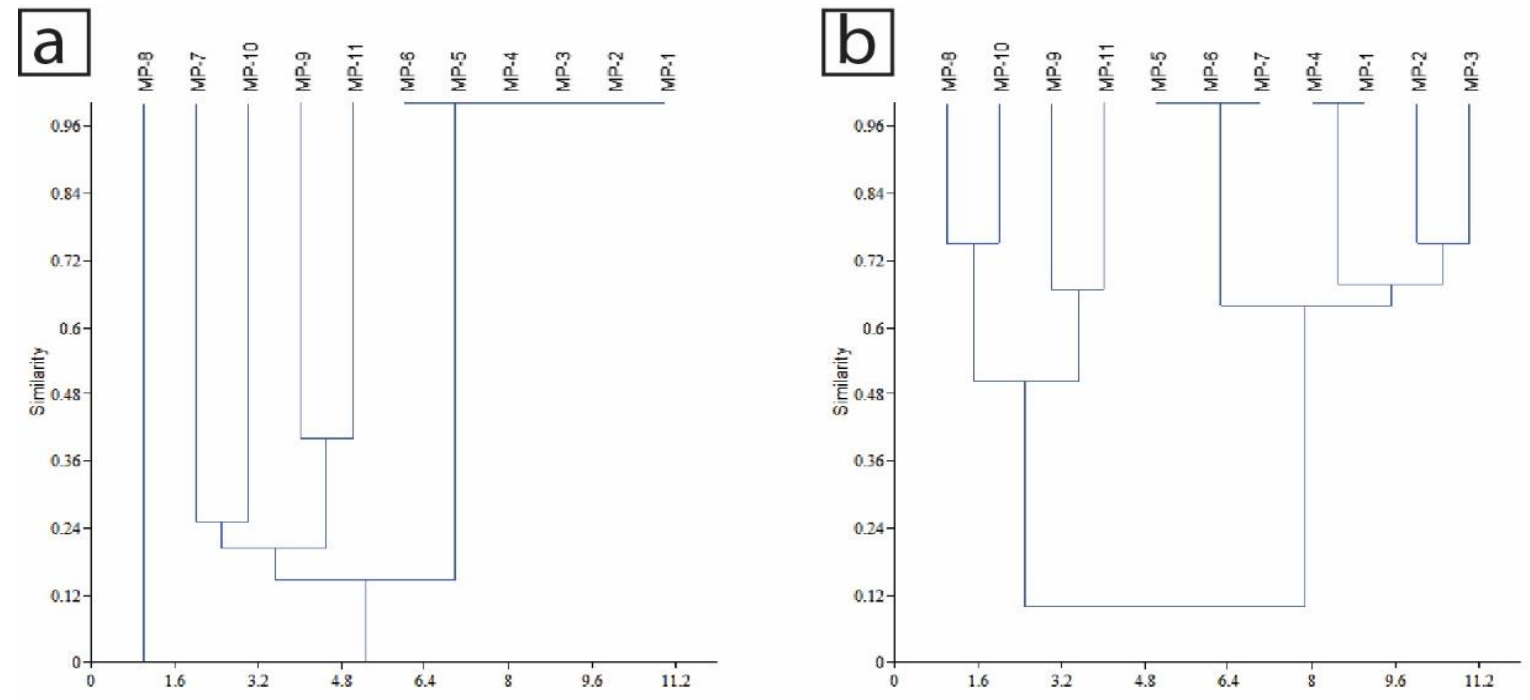

\section{Figure (7): Dendrogram obtained with UPGMA from the Jaccard dissimilarity matrix of eleven isolates of $M$. phaseolina derived from ISSR analysis. Distance is based on genetic similarity coefficient.}

\section{DISCUSSION}

In this study, M. phaseolina sesame isolates obtained from eleven different geographical regions in Egypt have been characterized through morphological characteristics, pathogenic variations, and molecular characterizations. In this respect, the obtained results showed some cultural variations among the isolates; however, morphological characteristics of the $M$. phaseolina isolates showed a wide range of diversity in colony color and colony sizes. The variation in mycelial growth and sclerotia diameter were statistically significant. This diversity indicated that this pathogen has improved its ability to adapt to a variety of environments and overcome growerimplemented host resistance (Trigiano et al., 2008), since environmental factors such as temperature, moisture, and soil types, as well as interactions with products of unknown genes in the genetic context, may alter these phenotypes (Marquez et al., 2021). Iqbal and Mukhtar (2014) found morphological variability across various isolates of M. phaseolina on multiple hosts in terms of growth, color, and pycnidium production. Similarly, Beas-Fern'andez et al. (2006) observed differences in morphology and pathogenicity among $M$. phaseolina isolates from various hosts as well as different parts of the same host.

The experiment of the pathogenicity demonstrated that all the isolates showed statistically significant variation in pathogenicity on sesame. M. phaseolina, has a wide variety of hosts and exits in two asexual forms which maintain its survival better (Almeida et al., 2003). M. phaseolina can survive in soil for two or more years in the absence of a host, depending on soil conditions (Gupta et al., 2012), which makes charcoal rot a difficult disease to control. Primary inoculum comes from seed, soil, and plant debris, and the severity of the disease is proportional to the amount of survived sclerotia in the soil (Ijaz et al., 2013). The present study proved that there is a relationship between the morphological characteristics and pathogenicity of the isolates. The highly pathogenic isolates of M. phaseolina MP-3, MP-9, MP-10 and MP-11 against sesame, produced large sized sclerotia. Likewise, isolates MP-1, MP-4, MP-6, and MP-8 which produced low sized sclerotia showed less pathogenicity against sesame. A similar pattern was observed in moderately pathogenic isolates.

The morphological heterogeneity might well be due to the fungi responses to environmental stimuli or variation in their hosts (Tok, 2019 and Pandey et al., 2020). Similarly, a high correlation between virulence and morphological variations has been reported by Tok (2019).

This finding is also consistent with the work of Edraki and Banihashemi (2010) and Purkayastha et al. (2004) who reported a relationship between morphological variations and pathogenicity. On the contrary, BeasFern'andez et al. (2006) and Iqbal and Mukhtar (2014) reported that pathogenicity has no relation with the size and weight of sclerotia.

(ITS) regions of the ribosomal RNA genes possess characteristics that allow pathogen 
identification (Mahmoud and Zaher, 2015). ITS sequencing of the 18S rRNA region has previously been used to identify $M$. phaseolina from a variety of hosts (Babu et al., 2007; Romanelli et al., 2014 and Khan et al., 2017). The ITS region was amplified using ITS1 and ITS4 primers for the eleven isolates, and the amplified PCR products produced one fragment of approximately $650 \mathrm{bp}$. Furthermore, the primers, MpKF1 and MpKR1 designed from the conserved sequences of the ITS region were highly specific and yielded a specific $350 \mathrm{bp}$ products. In the present study, all isolates belonged to the species M. phaseolina. Since this 350 bp amplicon was absent from other soilborne pathogens, it can be used for the speciesspecific identification of M. phaseolina (Babu et al., 2007).

To develop disease control systems and sesame breeding programs against charcoal rot, genetic variation within and between species must be understood (Salahlou et al., 2019). Molecular markers are ideal tools for assessing variation quickly within and among species (Sharma et al., 2013). In the present study, RAPD analysis clearly indicated high polymorphism among the $M$. phaseolina isolates from different geographical origins possessing different pathogenicity on sesame. The obtained molecular polymorphism was largely independent of geographical origin. Polymorphism generated by cluster analysis using the UPGMA method was correlated with the variation observed in the pathogenicity of isolates. The highly pathogenic isolates were separated in a different cluster from the less pathogenic. Isolates in a cluster which were collected from different geographical regions might share the same pathogenicity. In other molecular studies, high genetic diversity among isolates of Macrophomina was found considering different hosts and geographical origins. This is in agreement with Purkayastha et al. (2006) who found highly aggressive isolates for beans grouped separately from less aggressive ones, using PCR-RFLP. Živanov et al. (2019), when using RAPD markers, observed high variability among $M$. phaseolina isolates collected from different hosts in different countries.

Furthermore, the high genetic diversity among $M$. phaseolina isolates may be due to its pathogenic variability in plants as well as its ability to adapt to different agroecological conditions (Babu et al., 2010). Csondes et al. (2012) found that the pathogen's ability to grow and evolve under varying temperatures and $\mathrm{pH}$ conditions, cropping patterns, and transportation of the pathogen, these characteristics make it able to adapt to different environments and hosts, which are correlated with the genetic diversity of M. phaseolina isolates, which were obtained from different regions (Aghakhani and Dubey, 2009; Baird et al. 2010 and Iqbal and Mukhtar, 2014).

Similar results were reported by Khan et al. (2017), and Mahdizadeh et al. (2011) who indicated that different $M$. phaseolina isolates could not clearly be grouped according to geographical origins. This is in disagreement with the findings of Mayék-Pérez et al., (2001) and Jana et al., (2005) who reported that molecular markers could helpfully be used to group M. phaseolina isolates based on their geographical regions.

(ISSR) or microsatellites have been shown to be one of the most effective genetic markers in mycology (Bahkali et al., 2012). Microsatellite markers have been generated for several plant pathogenic fungi (Arias et al., 2011 and Mahdizadeh et al., 2012). In this study, ISSR genomic fingerprinting revealed a high level of heterogeneity among $M$. phaseoina populations. It is clear from the cluster analysis that isolates from closely geographical origins tend to group together, whereas in some cases they were placed in different clusters. The results of this study correspond with Mahdizadeh et al. (2011) who reported that isolates from the same host or the same geographic origin tend to group nearer.

Sánchez et al. (2017) and Tarakanta, et al. (2005), using SSR markers, reported that $M$. phaseolina isolates strongly tended to group according to their geographical origin. However, by using RAPD markers, clusters of $\mathrm{M}$. pseudophaseolina isolates were not linked to the host or the location where the pathogen was detected (Živanov et al., 2019).

RAPD and ISSR profiling techniques may provide useful information on the level of polymorphism and diversity in sesame isolates of M. phaseolina. The higher level of polymorphism detected by RAPD markers than with ISSR reveals the discriminating ability of both markers. The presence of genetic variants represented by the number of alleles at a locus and their frequency of distribution in a population is often the cause of polymorphism in each population (Powell et al., 1996). The disparity in resolution between RAPDs and ISSRs is most likely due to the fact that the two marker approaches target different parts of the genome (Bhattacharya et al., 2010). 


\section{CONCLUSION}

The increase in charcoal rot disease incidence still poses a major challenge and a great economic threat to important crops, even though chemicals and fertilizers are being widely used. Therefore, molecular characterization of $M$. phaseolina can help the understanding of the population genetics and biological parameters. The understanding of existing variability can be efficiently utilized to manage this disease, improve sesame yield, and help sesame breeding programs.

\section{REFERENCES}

Abd El-Ghany, S. 1998. Physiological, pathological and biochemical comparative studies on Macrophomina phaseolina isolates from different hosts. Menofia J. Agric. Res., 23(4): 885-906.

Aboshosha, S.S.; Atta-Alla, S.I.; El-Korany, A.E. and El-Argawy, E. 2007. Characterization of Macrophomina phaseolina isolates affecting sunflower growth in El-Behera governorate, Egypt. Inter. J. Agric. Biol., 9: 807-815.

Aghakhani, M. and Dubey, S.C. 2009. Determin ation of genetic diversity among Indian isolates of Rhizoctonia bataticola causing dry root rot of chickpea. Anton. Leeuw Int. J. Gen. Mol. Microbiol., 96(4): 607-619.

Al-Dhabaan, F.A.; Yousef, H.; Shoala, T.; Shaheen, J.; El Sawi, Y. and Farag, T. 2018. Enhancement of fungal DNA templates and PCR amplification yield by three types of nanoparticles. Journal of Plant Protection Research, 58(1): 66-72.

Almeida, ÁM.R.; Abdelnoor, R.V.; Arrabal Arias, C.A.; Carvalho, V.P.; Jacoud Filho, S.D.; Marin, S.R.R.; Benato, L.C.; Pinto, M.C. and Carvalho, C.G.P. 2003. Genotypic diversity among brazilian isolates of Macrophomina phaseolina revealed by RAPD. Fitopatol. Bras., 28: 279-285.

Almomani, F.; Alhawatema, M. and Hameed, K. 2013. Detection, identification and morphological characteristic of Macrophomina phaseolina: the charcoal rot disease pathogens isolated from infected plants in Northern Jordan. Arch. Phytopathol. Plant Prot., 46: 1005-1014.

Aly, A.A.: Abdel-Sattar, M.A. and Omar, M.R. 2006. Susceptibility of some Egyptian cotton cultivars to charcoal rot disease caused by Macrophomina phaseolina. J. Agric. Sci. Mansoura Univ., 31: 5025-5037.
Arias, R.S.; Ray, J.D.; Mengistu, A. and Scheffler, B.E. 2011. Discriminating microsatellites from Macrophomina phaseolina and their potential association to biological functions. Plant Pathol., 60: 709718.

Babu, B.K.; Reddy, S.S.; Yadav, M.K.; Sukumar, M.; Vijendra, M.; Saxena, A.K. and Arora, D.K. 2010. Genetic diversity of Macrophomina phaseolina isolates from certain agro-climatic regions of India by using RAPD markers. Indian J. Microbiol., 50: 199204.

Babu, B.K.; Saxena, A.K.; Srivastava, A.K. and Arora, D.K. 2007. Identification and detection of Macrophomina phaseolina by using species-specific oligonucleotide primers and probe. Mycologia, 99: 797-803.

Bahkali A.H.; Abd-Elsalam K.A.; Guo J.R.; Khiyami M.A. and Verreet J.A. 2012. Characterization of novel di-, tri-, and tetranucleotide microsatellite primers suitable for genotyping various plant pathogenic fungi with special emphasis on Fusaria and Mycospherella graminicola. International Journal of Molecular Science, 13: 2951-2964.

Baird, R.E.; Wadl, P.A.; Allen, T.; McNeill, D.; Wang, X.W.; Moulton, J.K.; Rinehart, T.A.; Abbas, H.K.; Shier, T. and Trigiano, R.N. 20 10. Variability of United States isolates of Macrophomina phaseolina based on simple sequence repeats and cross genus transferability to related genera within Botryosphaeriaceae. Mycopathologia, 170(3): 169-180.

Beas-Fern'andez, R.; De Santiago-de, S.A.; Hern'andez, D.S. and Mayek-P'erez, N. 2006. Characterization of Mexican and nonMexican isolates of Macrophomina phaseolina based on morphological characteristics, pathogenicity on bean seeds and endoglucanase genes. J. Plant. Pathol., 88: 53-60.

Bhattacharya, S.; Bandopadhyay, T. and Ghosh, P. 2010. Efficiency of RAPD and ISSR markers in assessment of molecular diversity in elite germplasms of Cymbopogon winterianus across West Bengal, India. Emirates Journal of Food and Agriculture, 22 (1): 13-24.

Bridge, P. 1998. Applications of PCR in Mycology: CABI.

CoStat. 2005. CoStat Program, version 6.4. CoHort software, Monterey, CA, USA

Csondes, I.; Cseh, A.; Taller, J. and Poczai, P. 2012. Genetic diversity and effect of 
temperature and $\mathrm{pH}$ on the growth of Macrophomina phaseolina isolates from sunflower fields in Hungary. Mol. Biol. Rep., 39: 3259-3269.

Csüllög, K. and Tarcali, G. 2020. Investigation of the mycelial compatibility of Macrophomina phaseolina. Folia Oecologica, 47 (2): 153158.

Deepthi, P.C.S.; Shukla, K.P.; Verma, R.E. and Siva Sankar. 2014. Identification of charcoal rot resistant lines of Sesamum indicum and chemical management of Macrophomina phaseolina, Medicinal Plants - Intl J Phytomedicines and Related Industries, 6: 3642.

Dhingra, O.D. and Sinclair, J.B. 1973. Location of Macrophomina phaseolina on soybean plants related to culture characteristics and virulence. Phytopathology, 63: 934-936.

Edraki, V., and Banihashemi, Z. 2010. Phenotypic diversity among isolates of Macrophomina phaseolina and its relation to pathogenicity. Iran. J. Plant Pathol., 46: 93100.

Etebarian, H.R. 2006. Evaluation of Trichoderma isolates for biological control of charcoal stem rot in melon caused by Macrophomina phaseolina. Journal of Agricultural Science Technology, 8(3): 243-250.

Fuhlbohm, J.; Ryley, M.J.; Aitken, E.A.B. 2013. Infection of mungbean seed by Macrophomina phaseolina is more likely to result from localized pod infection than from systemic plant infection Plant Pathol., 62: 1271-1284.

Gajera, B.B.; Kumar, N.; Singh, A.S.; Punvar, B.S.; Ravikiran, R.; Subhash, N. and Jadeja, G.C. 2010. Assessment of genetic diversity in castor (Ricinus communis L.) using RAPD and ISSR markers. Industrial Crops and Products, 32(3): 491-498.

Ghosh, T.; Biswas, M.K.; Guin, C. and Roy, P. 2018. A review on characterization, therapeutic approaches and pathogenesis of Macrophomina phaseolina. Plant Cell Biotechnol. Mol. Biol., 19: 72-84.

Gupta, G.K.; Sharma, S.K. and Ramteke, R. 2012. Biology, epidemiology and management of the pathogenic fungus Macrophomina phaseolina (Tassi) goid with special reference to charcoal rot of soybean. J. Phytopathol., 160: 167-180.

Hamza, H.; Abederrahim, M.A.; Elbekkay, M. and Ferchichi, A. 2013. Comparison of the effectiveness of ISSR and SSR markers in determination of date palm (Phoenix dactylifera L.) agronomic trait Am. J. Crop Sci., 7(6): 763-769.

Hussien, Z.N.; Ibrahim, M.M.; Ahmed, M.I.M. and Khalil, A.A. 2018. Thermotherapy of Sunflower Seeds Controlling Charcoal-Rot Caused by Macrophomina phaseolina. Egypt. J. Phytopathol., 46(2): 179-194.

Ibrahim, M.M.A. 2006. Studies of charcoal rot disease caused by Macrophomina phaseolina on sunflower and its control. Ph.D. Thesis, Fac. Agric., Ain Shams Univ.,148 pp.

Ijaz, S.; Sadaqat, H.A. and Khan, M.N. 2013. A review of the impact of charcoal rot (Macrophomina phaseolina) on sunflower. J. Agric. Sci., 151: 222-227.

Iqbal, U. and Mukhtar, T. 2014. Morphological and pathogenic variability among Macrophomina phaseolina isolates associated with mungbean Wilczek from Pakistan. The Scientific World Journal., Vol. 2014: 1-9.

Jana, T.; Sharma, T.R.; Prasad, R.D. and Arora, D.K. 2003. Molecular characterization of Macrophomina phaseolina and Fusarium species by a single primer RAPD technique. Microbiological Research, 158(3): 249-257.

Jana, T.K.; Singh, N.K.; Koundal, K.R. and Sharma, T.R. 2005. Genetic differentiation of charcoal rot pathogen, Macrophomina phaseolina, into specific groups using URPPCR. Can. J. Microbiol., 51: 159-164.

Khan, A.N.; Shair, F.; Malik, K.; Hayat, Z.; Khan, M.A.; Hafeez, F.Y. and Hassan, M.N. 2017. Molecular identification and genetic characterization of Macrophomina phaseolina strains causing pathogenicity on sunflower and chickpea. Frontiers in Microbiology, 8: 1309.

Kumar, D.G.; Natarajan, N. and Nakkeeran, S. 2016. Antifungal activity of nanofungicide Trifloxystrobin $25 \%$ + Tebuconazole $50 \%$ against Macrophomina phaseolina. African J. Microbiol. Res., 10: 100-105.

Machado, A.R.; Pinho, D.B.; Soares, D.J.; Gomes, A.A.M. and Pereira, O.L. 2019. Bayesian analyses of five gene regions reveal a new phylogenetic species of Macrophomina associated with charcoal rot on oilseed crops in Brazil. European Journal of Plant Pathology, 153: 89-100.

Mahdizadeh, V.; Safaie, N. and Goltapeh, E. M. 2011. Diversity of Macrophomina phaseolina based on morphological and genotypic characteristics in Iran. Plant Pathol. J., 27: 128-137.

Mahdizadeh, V.; Safaie, N. and Goltapeh, E.M. 2012. Genetic diversity of sesame isolates of 
Macrophomina phaseolina using RAPD and ISSR markers. Trakia J. Sci., 10: 65-74.

Mahmoud, A.G.Y. and Zaher, E.H.F. 2015. Why Nuclear Ribosomal Internal Transcribed Spacer (ITS) has been selected as the DNA barcode for Fungi?. Advancements in Genetic Engineering, 4 (2): 1-3.

Manici, L.M.; Cerato, C. and Caputo, F. 1992. Pathogenic and biological variability of Macrophomina phaseolina (Tassi) Goid. isolates in different areas of sunflower cultivation in Italy. $13^{\text {th }}$ Proceedings of International Sunflower Conference 1: 779784

Marquez, N.; Giachero, M.L.; Declerck, S. and Ducasse, D.A. 2021. Macrophomina phaseolina: General characteristics of pathogenicity and methods of control. Front. Plant Sci., 12: 634397

Mayék-Pérez, N.; López-Castañeda, C.; González-Chavira, M.; Garcia-Espinosa, R.; Acosta-Gallegos, J. and De La Vega, O.M. 2001. Variability of mexican isolates of Macrophomina phaseolina based on pathogenesis and AFLP genotype. Physiol. Mol. Plant Pathol., 59: 257-264.

Mezzomo, R.; Rolim, J.M.; Poletto, T.; Rosenthal, V.C.; Savian, L.G.; Reiniger, L.R.S. and Muniz M.F.B. 2018. Morphological and molecular characterization of Fusarium spp. pathogenic to ilex paraguariensis. Cerne, 24(3): 209-218.

Moulin, M.M.; Rodrigues, R.; Gonçalves, L.S.A.; Sudré, C.P., and Pereira, M.G. 2012. A comparison of RAPD and ISSR markers reveals genetic diversity among sweet potato landraces (Ipomoea batatas (L.) Lam.). Acta scientiarum. Agronomy, 34(2): 139-147.

Negreiros, A.M.P.; Júnior, R.S.; León, M.; Melo, N.J.; Michereff, S.J.; Ambrósio, M.Q.; Medeiros, H.L. and Armengol, J. 2019. Identification and pathogenicity of Macrophomina species collected from weeds in melon fields in Northeastern Brazil. Journal of Phytopathology, 167: 326-337.

Pandey, S.K.; Das, A.; Rai, P. and Dasgupta, T. 2015. Morphological and genetic diversity assessment of sesame (Sesamum indicum L.) accessions differing in origin. Physiol. Mol. Biol. Plants., 21: 519-529.

Pandey, A.K.; Burlakoti, R.R.; Rathore, A. and Nair, R.M. 2020. Morphological and molecular characterization of Macrophomina phaseolina isolated from three legume crops and evaluation of mungbean genotypes for resistance to dry root rot. Crop Prot., 127: 104962.

Powell, W.; Morgante, M.; Andre, C.; Hanafey, M.; Vogel, J.; Tingey, S. and Rafalski, A. 1996. The comparison of RFLP, RAPD, AFLP and SSR (microsatellite) markers for germplasm analysis. Mol. Breed., 2(3): 225238.

Premalatha. K.R.; Oviya, R.; Kannan, K.; Sabarinathan, G. and Ramamoorthy, V. 2020. Isolation and evaluation of various isolates of Macrophomina phaseolina causing dry root rot of sesame. Int. J. Curr. Microbiol. App. Sci., 9(7): 728-734.

Purkayastha, S.; Kaur, B.; Dilbaghi, N. and Chaudhury, A. 2004. Cultural and pathogenic variation in the charcoal rot pathogen from cluster bean. Ann. Agric. Biol. Res., 9: $217-$ 22.

Purkayastha, S.; Kaur, B.; Dilbaghi, N. and Chaudhury A. 2006. Characterization of Macrophomina phaseolina, the charcoal rot pathogen of cluster bean, using conventional techniques and PCR-based molecular markers," Plant Pathology, 55(1): 106-116.

Romanelli, A.M.; Fu, J.; Herrera, M.L. and Wickes, B.L. 2014. A universal DNA extraction and PCR amplification method for fungal rDNA sequence-based identification. Mycoses, 57: 612-622.

Salahlou, R.; Safaie, N. and Shams-Bakhsh, M. 2019. Using ISSR and URP-PCR markers in detecting genetic diversity among Macrophomina phaseolina isolates of sesame in Iran. Journal of Crop Protection, 8(3): 293309.

Saleh, A.A.; Ahmed, H.U.; Todd, T.C.; Travers, S.E.; Zeller, K.A.; Leslie, J.F. and Garrett, K.A. 2010. Relatedness of Macrophomina phaseolina isolates from tallgrass prairie, maize, soybean and sorghum. Mol. Ecol., 19: 79-91.

Sánchez, S.; Chamorro, M.; Henríquez, J.L.; Grez, J.; Díaz, I. and Santos, B.d.L. 2017. Genetic and biological characterization of Macrophomina phaseolina (Tassi) Goid. causing crown and root rot of strawberry. Chil. J. of Agric. Res., 77: 325-331.

Santos, K.M.; Lima, G.S.; Barros, A.P.O.; Machado, A.R.; Souza-Motta, C.M. and Correia, K.C. 2020. Novel specific primers for rapid identification of Macrophomina species. Eur. J. Plant Pathol., 156: 1213-1218. 
Sharma, G.; Verma, H. and Sharma, R. 2013. RAPD Analysis to study metagenome diversity in soil microbial community of arid zone plants. Proc. Natl. Acad. Sci. India. Sect. B. Biol. Sci., 83: 135-139.

Sucher, N.J. and Carles, M.C. 2008. GenomeBased approaches to the authentication of medicinal plants. Planta Medica., 74: 603623.

Tarakanta, J.A.N.A.; Sharma, T.R. and Singh, N.K. 2005. SSR-based detection of genetic variability in the charcoal root rot pathogen Macrophomina phaseolina. Mycological Research, 109: 81-86.

Tok, F.M. 2019. Relationship between morphologic, phenotypic and pathogenic characteristics in Macrophomina phaseolina Isolates from cucumber plants. Int. J. Innov. Approaches Agric. Res., 3: 651-660.

Trigiano, R.N.; Windham, M.T. and Windham, A.S. 2008. Plant pathology: concepts and laboratory exercises. CRC Press, Boca Raton, 217-234.

White, T.J.; Bruns, T.; Lee, S. and Taylor, J. 1990. Amplification and direct sequencing of fungal ribosomal RNA genes for phylogenetics. In: PCR Protocols: A Guide to Methods and Applications (eds Innis MA, Gelfand DH, Sninsky JJ \& White TJ), pp. 315-322. Academic Press, San Diego.

Yao, H.; Zhao, Y.; Chen, D.F.; Chen, J.K. and Zhao, T.S. 2008. ISSR primer screening and preliminary evaluation of genetic diversity in wild populations of Glycyrrhiza uralensis. Biol Plant, 52: 117-120.

Živanov, S.T.; Dedić, B.; Dimitrijević, A.; Dušanić, N.; Jocić, S.; Miklič, V.; Kovačević, B. and Miladinović, D. 2019. Analysis of genetic diversity among Macrophomina phaseolina (Tassi) Goid. isolates from EuroAsian countries. Journal of Plant Diseases and Protection, 126: 565-573. 